\title{
Research on the Sustainable Development of Marine Tourism of Danjia Culture in Qinzhou of South China
}

\author{
Wei Huang ${ }^{1, a}$, Yanping Dai ${ }^{2,3, a}$, Ruwen Liang ${ }^{3, a}$, Yuanjun Huang ${ }^{3}$, Qiuhua \\ Cheng $^{3}$, Yeling Tan ${ }^{3}$, Daobo Wang ${ }^{3, b}$, Zhilian Fan ${ }^{1, b}$ \\ ${ }^{1}$ College of agriculture, Guangxi university/ Research Center of Beibu Gulf Marine Culture, China \\ ${ }^{2}$ College of Business, Guangxi University, China \\ ${ }^{3}$ College of Resources \& Environment, Qinzhou University, China
}

ãEuivalent contribution author: 504081114@qq.com(WH), 757998657@qq.com(YD), 46679811@qq.com(RL);

bCorresponding author: 363583837@qq.com(DW); 464259744@qq.com(ZF)

\begin{abstract}
Keywords: Sustainable development; leisure tourism; Danjia culture; marine culture; Beibu Gulf Abstract. It is one of the important methods to promote the sustainable development of tourism to fully tap the marine culture, enrich the modern leisure tourism. Danjia live in Qinzhou for many years and form a unique cultural. From the clothing, ship, shed of Danjia, this article analyzes its cultural factors firstly. Then it analyses the historical and cultural value; appreciation of the aesthetic value such as food, clothing, living room, festival ritual customs etc; experience value such as making and tasting seafood delicacy, making Danjia jewellery, visiting the temple, taking part in dragon-boat race on the sea and their wedding. Finally, it points out some suggestions for developing marine tourism of Danjia culture, such as respecting for nature and promoting sustainable development; planning rationally and building a good ecological tourism area; optimizing management mechanism, strengthening supervision and so on.
\end{abstract}

\section{Introduction}

Danjia is a collective name for the fishermen and residents who lives in the Pearl River downstream in the various branches of the water flow. Its origin can't be investigated. There are two versions about it. One refers to the early Han people in southern China; another is Guyue people or Guli people, who are excluded by the people who lived on land, and they lived on the sea over the years. It is not an independent nation, but a general designation of the residents living in the coastal water in China, and it belongs to the Han nationality ${ }^{[1]}$. They live on the sea with a boat as a home all the year. Located in the Qinzhou Gulf, Xiniujiao town where Danjia people gathered has convenient waterway transportation, and this provides a good opportunity for the development of marine tourism on Qinzhou Danjia culture. Based on mangroves and favourable terrain of the Qinzhou Gulf and taking boat as home, Danjia people create a rich spiritual civilization and material civilization and form a unique cultural landscape and distinctive folk culture in the long historical development. These have high value of tourism development and they have attracted domestic and foreign tourists as important marine tourism resources.

\section{Danjia Cultural Factors of Qinzhou Ocean Cultural Tour}

Danjia

Danjia people are also called Dan or slug. It is an ethnic group who live on the water; they take boat as home, live on fishing... The intellectual were not allowed married with them and they are not allowed to live on the land.

\section{Danjia Clothing}

The traditional Danjia clothing is mainly included Dan coats, hats, belts and pants. With woven bamboo and bamboo leaves, bamboo hat has two kinds of shapes: dome and spire. In the inside of the 
hat, there is a little bamboo to fix and symmetrical tether connected by a rope. The main colour of daily Danjia clothing is black and blue. The Cuff is wide and sleeve short, trousers is wide and short. Women's trousers are wide than that of man's. So there need a belt to fix it. And the belt is mainly used for anti wet which is embroidered by beautiful pattern ${ }^{[2]}$.

\section{Jiakou Boat}

All the family of Danjia take boat to the sea, and every boat is a family. Dan people ride the boat like an egg on the flat section, the upper cover to canopy, named Dan boat. A boat is a floating house, generally 6 meters long, and 1.2 meters wide, the structure is divided into two compartments, the front plate can move, when working off, ferry passengers and tourists sit on both sides of it, in the middle of the boat it is used to load. It is the bedroom of the family when putting down the activity board at night. The back of the boat is one step higher than the front, which is used to store clothing, worship god. It is used to store things in the end of the boat. The boat is divided in sections, which can be pushed, and pulled. When it is operated it can be overlapped. And at night or raining days it can push to cover the whole boat. When the boat is in the sea, all the family go with it to live on the sea. The boat is a house and also is a productive tool. Every family has a boat. When children grow up and got married, they will have their own boat. After the establishment of People's Republic of China, the Usually, the elderly live in the shed. When the holidays or weddings, family gather together in Danjia shed ${ }^{[3]}$.

\section{Tourism Value of Danjia Culture in Qinzhou}

The specific research value is reflected in the following three aspects:

\section{Historical and Cultural Value}

Danjia culture has a long history. According to the related research, Danjia history can be traced back to the period of Jin Dynasty ${ }^{[4]}$. At that time nations were live together with Dan, after the Jin Dynasty; there were more historical records on Danjia. The book "Gui Hai Yu Heng Chronicles" said that the Danjia people are people who live on the sea. The book "Ling Wai Dai Da" of Song Dynasty said Danjia people live in boat on the sea just like living on land. The book "Tai Ping Huang Yu Ji" said that Danjia people would be more death if there live on land.

The rulers ruled harsh on Danjia people, which lead Danjia people live a poor life. They are not allowed to live on the land, to school and to marry with people who live on the land until the liberation. Therefore, history of existence and development of Danjia people is a microcosm of the history of the national development process. So Danjia culture has a very high research value of history and culture, and it is very valuable information for researching on similar history and folk culture in future.

\section{Appreciation of the Aesthetic Value}

(1) Diets. Danjia diet of Xiniujiao in Qinzhou not only retains the unique flavor, but also has the cultural connotation of" love, courtesy, beauty". For example: "the seafood pot" (i.e. the Dan family portrait) with a variety of sea treasures, unique style, taste delicious, meaning reunion happy ${ }^{[5]}$. Seafood soup, seafood soup, Spicy Seafood snacks are unique flavor.

(2) Clothes \& Accessories. Many men and women wear Danjia cloth pants. And the color blue is mainly black and the overall simple, underwear short sleeves, wearing a hat to against the wind and rain, there are beautiful patterns on the waist belt which provides the convenience of operation ${ }^{[6]}$. In a word, Danjia family clothing, hats and ornaments contained rich marine style.

(3) Habitable Room. With the boat for Danjia family room, day boat fishing inhabits, different styles, special decoration, plus Shanghai Jing Ying lining, can form unique and beautiful scenery of fishing. In addition to fishing boats, about two or three meters away from the seacoast to build shed is also filled with fishermen style architecture. As they pile with several logs, fence or old ship shed as a building wall, the old ship shop floor, bamboo tile or asphalt felt cover Danjia shed roof. The diet is divided into a stall and the rest of the bedroom. Hall, room is very small, has opened a window for 
ventilation, bright. This simple shed building to outsiders can be said to be unique, novel and attractive.

(4) Festival Custom. "Wedding at sea", "Tug-of-war", "salty-water song" and other activities express their feelings in the form of song ${ }^{[7]}$.During the Festival worship, people dressed in festive costumes for a grand worship ceremony to hold many worship activities, such as on the day of Pingan and Xufu of January, the birthday of Shewang and Guanyin in February, the birthday of Beidi in March, the birthday of Guandi and Longmu in May.The birthday of Shewang at the beginning of August and December sixteen (these festivals in ritual calendar), grand scenes, Lions Dance, lively and extraordinary, will give each participant impressed.

\section{Participation Experience Value}

Study on Ecotourism in Xiniujiao of Qinzhou ,Danjia cultural theme can be highly participatory, and in various forms, rich in content.

(1) Making and tasting seafood. Danjia have a wide variety of food, practice varied, visitors enjoy the food and can personally cook to experience fun.

(2) Making Unique Ornaments. Learn Danjia girl making beautiful belt to your sweetheart, who shows good feelings between lovers, and make a simple headdress ${ }^{[2]}$. For example married women wearing the snout, brightly colored mottled, making exquisite patterns and clear lines.And the hair on the other, some hairpin ornaments, and five horns braided tie unmarried girl need simple and delicate decorations.

(3) Temple of worship. Danjia have many sacrificial activities, which are unique. Especially, folk performances and sacrificial activities are traditional ritual activities oriented which shows the unique cultural characteristics of Danjia. For example, they dressed in costumes and use decorating car to carry 50 pigs and fruit offerings to worship the scene. The scene is lively, Danjia women also sang the melody melodious song ${ }^{[8]}$.

(4) Wedding on the sea. "Making fun of wife"" sailing the boat" in the wedding and other activities will have a lot of experience value for tourists involved. The boatmen who reverse direction in the same boat sail the boat and make it shaking. Al those to make the wife can adapt to live on the sea.

(5) Dragon-boat Racing. Every the 5th day of May the Chinese lunar calendar, Danjia family holds dragon boat race activities on the sea. They believed that the dragon boat race can avoid epidemics. There is a saying that "The sound of dragon drum let ghost go" ${ }^{[9]}$.So usually the day will be a busy day.

In general, visitors can learn to dance, live Danjia studio, travel on the sea, fish in the sea, and have recreational sports activities on the mangrove sand ${ }^{[10]}$. The growth condition can be observed in mangrove marine life and living environment and living habits, such as oysters, shrimp, jellyfish, crabs, sea ducks, gulls and other fish.

\section{Suggestions on Developing Marine Tourism on Danjia Culture}

Qinzhou Danjia culture of marine tourism should rely on the carrier of the Beibu Gulf Economic Development Zone", and the background of "hometown of Dolphin ", "Qinzhou Bay Mangrove Wetland Nature Reserve, Qinzhou Maowei national Ocean Park", and create Danjia cultural tourism routes, highlight the mind of history, culture and entertainment. Then according to the Qinzhou Danjia family living, living habits and cultural heritage of the status quo, adopt the mode of experiential mangrove ecotourism + Danjia cultural industry to build a unique cultural ecological tourism area of Danjia in Xiniujiao of Qinzhou.

\section{Respect for Nature; Lead a Comprehensive, Coordinated and Sustainable Development}

With the development of society, Danjia has built a building on the shore. They have the fixed residence on the land. There are less people who live in a boat and on the sea. We should protect the Danjia culture, which are on the verge of extinction, such as "picking up pearl underwater, Tug-of-war on boat, rowing boat, salty-water song, say hello to parents-in law in the morning and 
night, sea sacrificial ceremony during Festival". In addition, do not lead mangrove Danjia cultural ecological tourism to vulgarization and "pseudo folk custom", try to make the original Danjia traditional culture in front of the public, so that they experience the Danjia cultural and ecological tourism and have fun at the same time, also felt spirits of Danjia family to have courage to take risks, optimistic, respect for nature.

\section{Plan Rationally and Create a Good Ecological Tourism Area}

Do overall planning research for Danjia family living environment. At the same time, it should make a reasonable planning and research on the mangrove ecological environment. Because they are indispensable. Danjia family lost mangrove protection, Danmin culture will not be able to rely on. Mangrove lost Danjia culture; mangrove culture will become the "tragedy of the commons".

Optimize the Management Mechanism, Strengthen Supervision

Pay attention to the construction of personnel training and team, strengthen professional training, improve the management mechanism, establish the Danjia culture marine tourism management mechanism in Qinzhou, form Danjia cultural special management team, strengthen the protection and management of ecological tourism. Understand the connotation of Danjia cultural and ecological tourism correctly and avoid the protection type of closed and solidification.

\section{Acknowledgements}

This work was financially supported by Key Project of Research Center of Beibu Gulf Marine Culture(2015BMCC04); Science and Technology Research Project of Guangxi Universities (KY2015LX525).

\section{References}

[1] L.R. Pan. LifeFrom the sea to the land--on Beihai Danjia cultural tourism. Market Forum Vol. 9 (2011), p. 86-88

[2] H.L. He. Research of Sanya Danjia marine folk and social function . J Anh.Agr. Sci Vol. 4 (2016), p. $199-200,300$

[3] H.L. He, M. Deng, G.J. Zhu, etal. Sanya Danjia cultural preservation mode . J Anh.Agr. Sci. Vol. 21 (2013), p. 8987-8988

[4] L. He. Sanya Houhai Danjia coastal tourism ethnography study. National Forum Vol. 1 (2016), p. 103-107

[5] B.N. Sun,C.X. Fan, J. Wen. City of rapid development under the background of regional culture inheritance and Innovation. Guangdong Gardens Vol. 2 (2015), p. 20-24

[6] H.J. Zhang. Study on Beihai Danjia people's folk culture tourism development. J Wuzh. Uni. Vol. 4 (2011), p. 7-12

[7] Y.J. Xie. Dongguan Danjia water of songs. Sea Song Vol. 3 (2014), p. 57-59

[8] J.X. Wei, Z.Y. Li. "Sea spirit": Beihai Danjia song research. J Guangxi Normal College Vol. 3 (2014), p. 14-20

[9] Q.G. Liu. Guangxi Beihai Danjia traditional taboo culture. Legal system and society Vol. 31 (2011), p. 245-246

[10] H.N Chen, Y.R. Peng,C.H. Yuan. "The development of water residents" traditional folk sports and the characteristics of coastal leisure tourism. J sports adult education Vol. 1 (2012), p. 52-54 